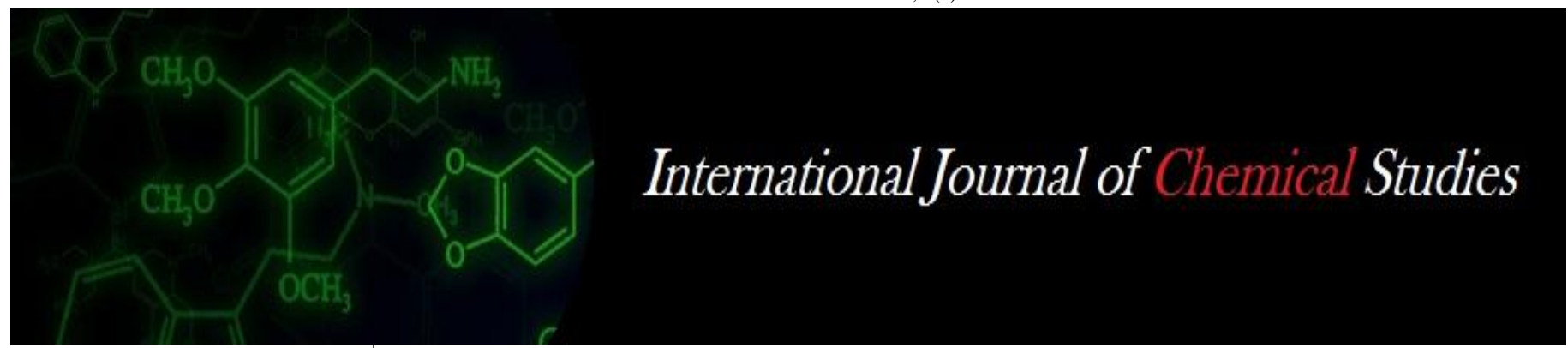

P-ISSN: 2349-8528

E-ISSN: 2321-4902

IJCS 2020; 8(1): 1672-1676

(C) 2020 IJCS

Received: 27-11-2019

Accepted: 30-12-2019

Umair Nazir Wani M. Tech Renewable Energy, Mewar University, Rajasthan, India

Nasir UL Rasheed Rather Senior Scientist, CSIR-Central Mechanical Engineering Research Institute, Durgapur, West Bengal, India

Siva Brahmaiah Rama V Head, Department of Electrical Engineering, Mewar University, Rajasthan, India
Corresponding Author: Umair Nazir Wani M. Tech Renewable Energy, Mewar University, Rajasthan, India

\section{Studies of solar air conditioning system based on triple effect refrigeration}

\author{
Umair Nazir Wani, Nasir UL Rasheed Rather and Siva Brahmaiah Rama V
}

DOI: https://doi.org/10.22271/chemi.2020.v8.i1x.8505

\begin{abstract}
A solar powered air-conditioning system designed for heating and cooling was put into operation and studies regarding the same triple effect refrigeration through solar thermal energy was carried out. Water, lithium bromide and other chemicals were used in the vapor absorption machine. Chiller having a capacity of $100 \mathrm{kw}$ i.e. $30 \mathrm{TR}$ was operated on the temperature of $210{ }^{\circ} \mathrm{C}$ obtained from solar field depending upon the solar radiations. This is the main part of the whole system because the heat produced by the solar field is used here for converting it into the chilling effect. The generator design of the machine allowed the use of hot water in the temperature range of $140-210{ }^{\circ} \mathrm{C}$. The measured volumetric flow rate of hot water delivered by generator pump was ranging from 2 to $5.6 \mathrm{~m}^{3} / \mathrm{h}$.
\end{abstract}

Keywords: Solar, air conditioning, triple effect refrigeration, absorption, cooling, renewable energy, Li$\mathrm{Br}$, absorber, absorbent

\section{Introduction}

Due to continuous increase in energy prices and the adverse environmental impact accompanying the use of conventional fuels suggest that it is opportune to reconsider the use of renewable energy resources, such as solar energy. Perhaps the most appropriate application of solar energy is for cooling purposes, where the need for cooling increases with solar intensity. One of well-known heat operated methods for producing cooling is absorption air conditioning cycles. Such cycles have been applied commercially using low temperature steam as a heat source. Since the operation of these cycles can be achieved with low grade heat therefore it is possible to use solar energy to run for absorption refrigeration cycle.

Absorption air-conditioning systems are similar to vapor compression air-conditioning systems, but differ in the pressurization stages. In general, an absorbent in the low-pressure side absorbs an evaporating refrigerant $\left(\mathrm{H}_{2} \mathrm{O}\right)$. The most usual combinations of chemical fluids used include lithium bromide-water $\left(\mathrm{LiBr}-\mathrm{H}_{2} \mathrm{O}\right)$, where water vapor is the refrigerant and ammonia-water $\left(\mathrm{NH}_{3}-\mathrm{H}_{2} \mathrm{O}\right)$ system where ammonia is the refrigerant. Most of the absorption cooling cycles use either $\mathrm{LiBr}-\mathrm{H}_{2} \mathrm{O}$ or $\mathrm{NH}_{3}-\mathrm{H}_{2} \mathrm{O}$ solutions. In solar applications the $\mathrm{LiBr}-\mathrm{H}_{2} \mathrm{O}$ system is superior to the $\mathrm{NH}_{3}-\mathrm{H}_{2} \mathrm{O}$ system for several reasons. Among these reasons are that the $\mathrm{LiBr}-\mathrm{H}_{2} \mathrm{O}$ system is simpler in design and operation, and cheaper in cost as compared to the $\mathrm{NH}_{3}-\mathrm{H}_{2} \mathrm{O}$ system. Also, the $\mathrm{LiBr}-\mathrm{H}_{2} \mathrm{O}$ system can operate at a low generator temperature and this range of temperature the system has a COP (Coefficient of Performance) higher than that of the $\mathrm{NH}_{3}-\mathrm{H}_{2} \mathrm{O}$ system. The $\mathrm{LiBr}-\mathrm{H}_{2} \mathrm{O}$ can be operated by the simple flat plate collectors while the $\mathrm{NH}_{3}-\mathrm{H}_{2} \mathrm{O}$ systems operated with evacuated tubes collectors or solar concentrators. The $\mathrm{NH}_{3}-\mathrm{H}_{2} \mathrm{O}$ system is restricted in building applications because of the hazards associated with the use $\mathrm{NH} 3$ whereas $\mathrm{LiBr}-\mathrm{H}_{2} \mathrm{O}$ systems are safe.

The lithium bromide-water absorption chiller is one of the favourites due to the following specific reasons:

1. It can be thermally driven by gas, solar energy, and geothermal energy as well as waste heat, which help to substantially reduce carbon dioxide emission;

2. Its use of water as a refrigerant.

3. It is quiet, durable and cheap to maintain, being nearly void of high speed moving parts;

4. Its vacuumed operation renders it amenable to scale up applications. $\mathrm{LiBr}-\mathrm{H} 2 \mathrm{O}$ absorption chillers enjoy cooling capacities ranging from kilowatts $(\mathrm{kW})$ to megawatts $(\mathrm{mW})$ which match with small residential to large scale commercial or even industrial cooling needs. 
Several eminent people have performed research studies on energy efficient source for cooling and refrigeration. Rasul, M.G. and Murphy, A. $1984^{[1]}$. Had evaluated the feasibility of an absorption refrigeration unit on solar power. A prototype model that was capable of producing a temperature change in the evaporator was designed, fabricated and tested. The performances and effectiveness of the unit was studied by determining refrigeration effect (RE), coefficient of performance (COP) and explaining operational issues of the unit. Uppal, A.H. et al. $1986^{[4]}$. Made a simulation about a low temperature solar operated absorption machine for vaccine storage for capacity of 56liters with no moving parts for remote locations for this, conventional absorption-cycle and solar-energy systems have been modified and coupled in a novel way to produce a reliable, low-cost refrigeration unit. Yeung, M.R. et al. $1992^{[6]}$. Showed the performance of a solar-powered air conditioning system in Hong Kong city of Japan. They made a study for showing the feasibility of utilizing solar power for comfort cooling in Hong Kong. They designed a solar-powered absorption constructed on the campus of the University of Hong Kong. In their studies they demonstrated the design of the HKU solar-powered airconditioning system detail and its performance over an entire cooling season was also discussed and compared with similar systems in Italy and Singapore. It was found that the HKU solar air-conditioning system had an annual system efficiency of $7.8 \%$ and an average solar fraction of $55 \%$.
Meunier.F.1994 [7]. discussed the solar thermal application for cooling and reported that the liquid adsorption systems are very attractive for air conditioning without producing any harmful effect for environment and conservations of primary energy source. Very interesting results were obtained with dry sorption systems make these systems very good candidate for further future developments.

\section{Materials and Methods}

Solar absorption air-conditioning plant consisting of four main water streams flowing though the generator, evaporator, condenser and absorber. Forty eight parabolic trough type collector modules with an absorber area of $5.9 \mathrm{~m}^{2}$ each were used to energize the system. The individual collector modules were connected sharing the same manifold. However, the rows of collectors were connected in parallel to keep the pressure drop low in the circuit. Pressure drop and pumping energy has been previously known as being a controlling factor in solar cooling scheme economics. Glass pipes were provided in the main primary circuit and the row connections were made up copper pipes. The collectors supplied heat to a vapor absorption machine. Primary hot water was circulated through the parabolic trough collector panels and heated up to $210{ }^{0} \mathrm{C}$ by incidence of solar energy on the aluminium absorber plates. The heat produced was transferred to a storage tank via a plate heat exchanger.

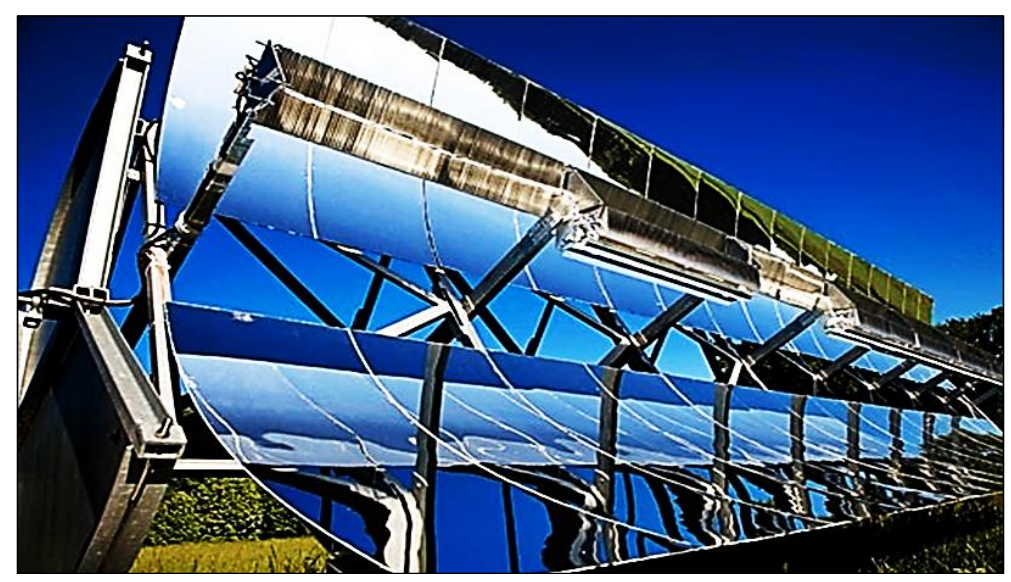

Fig 1: Parabolic trough collectors

At about $170{ }^{\circ} \mathrm{C}$ prevailing heat was supplied to the generator of a $100 \mathrm{~kW}$ nominal cooling capacity $(\mathrm{LiBr} / \mathrm{H} 2 \mathrm{O})$ absorption chiller, which operated in vacuum. This was to boil a weak solution of solvent and refrigerant (lithium bromide and water), that resulted in a strong solution. The refrigerant vapors were condensed on the condenser tubes. The condensate was throttled through an expansion device obtaining two-phase refrigerant; the liquid refrigerant evaporated under low pressure in the evaporator, thus producing cooling. Chilled water flowing through the evaporator tubes was supplied to the fan coil units at about 7 ${ }^{0} \mathrm{C}$. Meanwhile, the strong solution from the generator passed through a counter flow heat exchanger to preheat the weak solution entering the generator. In the absorber, the refrigerant vapor from the evaporator was absorbed in the strong solution. The heat of condensation and absorption was removed from the system by means of cooling water entering/leaving the chiller at about $30-35{ }^{\circ} \mathrm{C}$ flowing through the tubes of the absorber and condenser in parallel connected to a forced draft cooling tower. The solution was circulated by a mechanical pump. However, pumps were used to circulate water between the collector array and the plate heat exchanger, plate heat exchanger and storage tank, storage tank and generator, cooling tower and absorber/condenser and fan coil units and evaporator. Thermal energy was supplied entirely by solar collectors. 


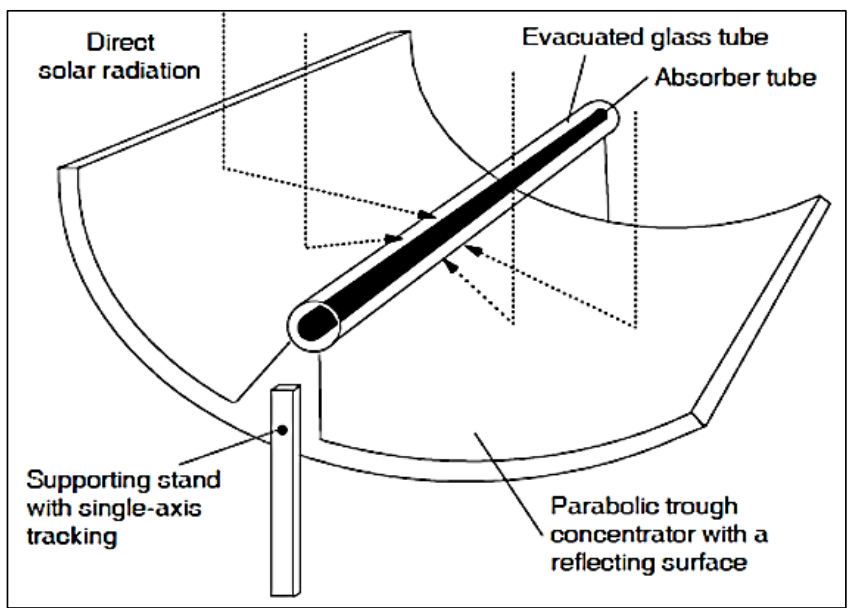

Fig 2: Mechanism of operation of a Parabolic Trough Collector.

Solar powered $\mathrm{LiBr}-\mathrm{H} 2 \mathrm{O}$ absorption systems mainly consist of following components.

(A) Solar field.

(B) Tracking control panel.

(C) Vapor absorption machine.
(D) Cooling tower.

(E)Water treatment system

(F) Electric motor control panel.

(G) Control room

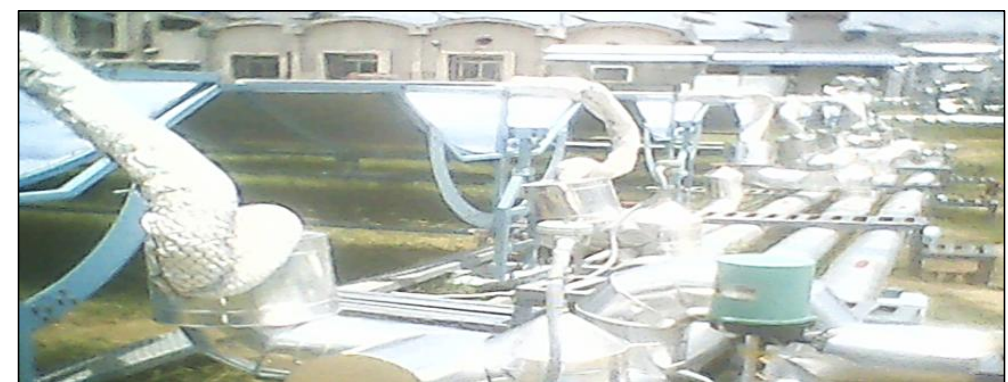

Fig 3: Photo the schematic arrangement of the solar field showing the arrangement of the flow of the heat transfer fluid via parabolic trough with temperature sensors and flow meters.

\section{Results \& Discussion}

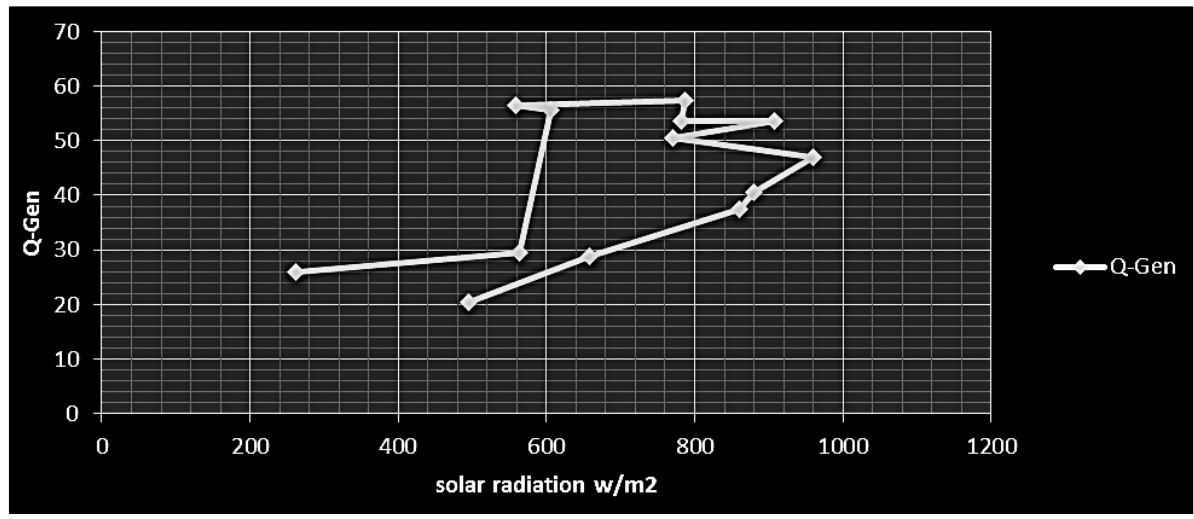

Fig 4: Effect of the solar radiations on the heat dissipated by Generator.

Q-Gen: This was defined as a total heat dissipated by the generator in the vapor absorption machine. This was a function of the flow rate of the hot water to the generator and temperature difference between hot water inlet and outlet temperature of the generator obtained from the solar field. Temperature from the solar field to the generator of the machine was totally dependent upon the solar radiations obtained at a particular instant, because higher the value of radiations higher will be the generator temperature. A graph showing the relation between solar radiations and heat dissipated by the generator shown below. It showed that as the value of the radiations goes to increase from morning, temperature of the solar field increases leading to increase in the temperature of the generator. From this graphical analysis it was clear that as the value of solar radiation goes to increase from 10:00 to 14:45 it also lead to linear increasement in the value of the Q-Gen. and decrease with respect to decrease In the solar radiation value from 15:00 t0 17:00 or up to evening and found that the maximum value of Q-Gen obtained was 56 $\mathrm{KW}$ on the $628 \mathrm{w} / \mathrm{m}^{2}$ radiations on that day after maintaining a constant temperature of the generator. 


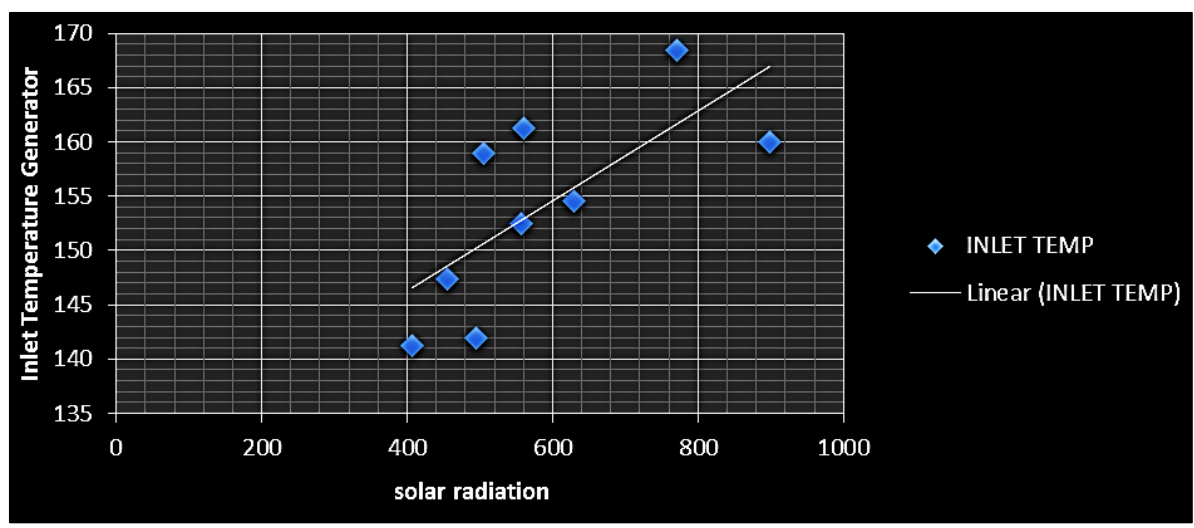

Fig 5: Effect of the solar radiations on Generator inlet temperature

Graph showed that the generator inlet temperature of the V.A.M. had a linear relationship with respect to the solar radiations, which are ranging from 313.5 up to the $898 \mathrm{w} / \mathrm{m}^{2}$. It was found that as the value of the solar radiations goes to increase it also made an increasement in inlet temperature of the generator from zero to $169{ }^{0} \mathrm{C}$. As solar radiations goes down in the evening it also decrease the inlet temperature of the generator. Graph shows that when radiations are about 400 temperature of the V.A.M. also very low, but it goes to $169^{\circ} \mathrm{C}$ at a radiations of $898 \mathrm{w} / \mathrm{m}^{2}$.

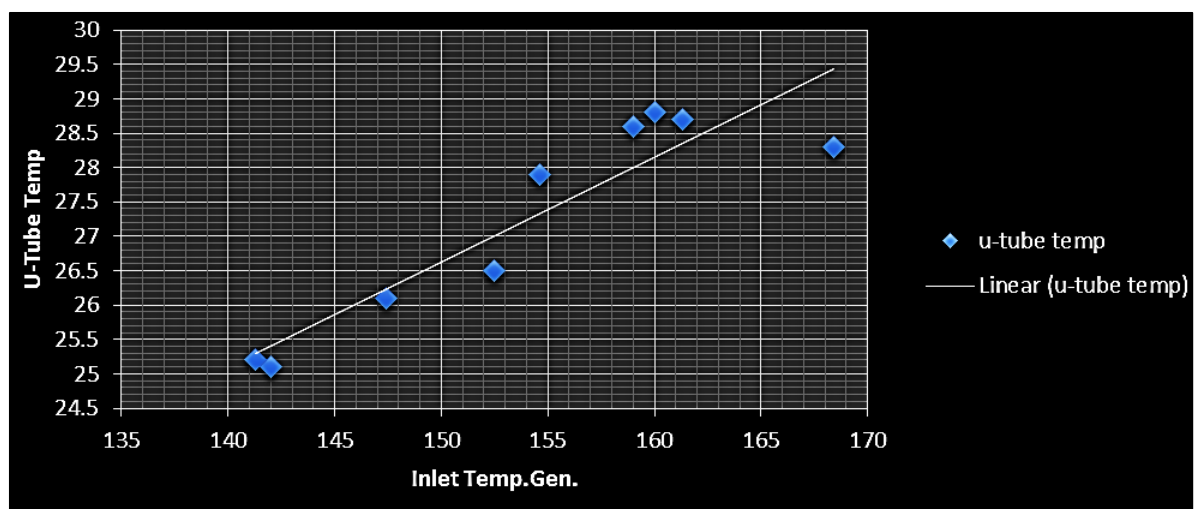

Fig 6: Effect of Generator Temperature on Evaporator Temperature (U-Tube).

Evaporator temperature is also known as U-Tube temperature. A graphical analysis between the generator temperature and evaporator temperature is shown below. This shows that the value of the generator temperature was varying from $142{ }^{\circ} \mathrm{C}$ to $169.5^{\circ} \mathrm{C}$ and it also changed the evaporator temperature ranging from 24.5 to $28.8{ }^{\circ} \mathrm{C}$ with respect to every instant change in the generator temperature. Graphical results showed that as the generator temperature increases it also increases the evaporator temperature. It showed that when the generator temperature was $142{ }^{\circ} \mathrm{C}$, evaporator temperature was just 25.1 ${ }^{0} \mathrm{C}$, but its value goes too increased up to $28.8{ }^{0} \mathrm{C}$ when generator temperature was $169.5{ }^{\circ} \mathrm{C}$. At last, higher value of the generator also increased evaporator temperature.

\section{References}

1. Rasul MG, Murphy A. Solar Powered Intermittent Absorption Refrigeration Unit. Sol energy matter sol cells 46, 1984.

2. Izquierdo M. Tinaut D. Solar-heated absorption system: experimental results for summer period. In: Ponencian, Poster and Proceedings of the XXIII Renc Int COMPLES: la Energi'a Solar en la Cooperacio'n NorteSur; 1985, Sevilla, España: 427-32, 1984.

3. Iloeje OC. Quantitative comparisons of treated $\mathrm{CaCl}_{2}$ absorbent for solar refrigeration. Solar Energy. 1986; 37(4):253-260.

4. Uppal AH, Norton B, Probert SD. A low-cost solarenergy stimulated absorption refrigerator for vaccine storage. Applied Energy. 1986; 25(3):167-174.
5. Staicovici MD. An autonomous solar-powered ammoniawater refrigeration system. Solar Energy. 1991; 36(2):115-124.

6. Yeung MR, Yuen PK, Dunn A, Cornish LS. Performance of a solar-powered air conditioning system in Hong Kong. Climate change Energy and the environment. Solar Energy. 1992; 48(5):309-319.

7. Meunier F. Thermal application Sorprtion solar cooling. Renewable Energy. 1994; 5(1-4):422-429.

8. Bansal NK, Blumenberg J, Kavasch HJ, Roettinge T. Performance testing and evaluation of solid absorption solar cooling unit. Solar Energy. 1997; 61(2):127-140.

9. Nasir UL. Rasheed Rather, Sheen Moses, Umakanta Sahoo, Arun Tripathi. "Performance Evaluation of Hybrid Cold Storage Using Solar \& Exhaust Heat of Biomass Gasifier for Rural Development". International Journal on Recent and Innovation Trends in Computing and Communication. 2017; 5(7):563-. https://ijritcc.org/index.php/ijritcc/article/view/1088.

10. Nasir UL. Rasheed Rather et al. "Characterization, evaluation and optimization of a renewable energy based cold storage unit using biomass gasification, solar thermal energy and waste to heat energy technologies" published in Internation journal of chemical studies. 2017; 5(4):1875-1879.

11. Nasir UL. Rasheed Rather et al. Performance evaluation and COP calculation of Triple effect vapour Absorption machine working on Solar Thermal energy published in International Journal of Current Engineering and 
Technology EISSN 2277 - 4106, P-ISSN 2347 - 5161. 2018; 8(1).

12. Nasir UL. Rasheed Rather et al. characterization and evaluation of solar biomass hybrid model based on thermodynamic analysis to run a thermal power plant published by IMPACT: International Journal of Research in Engineering \& Technology ISSN (P): 2347-4599; ISSN (E): 2321-8843. 2018; 6(1)1-14. 